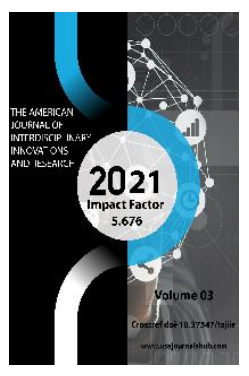

\title{
Characterization Of A Bacterium - Producer Of Amidase
}

Lobar Khasanova

Researcher, National University Of Uzbekistan, Tashkent, Uzbekistan

Journal Website:

https://theamericanjou

rnals.com/index.php/ta

jiir

Copyright: Original content from this work may be used under the terms of the creative commons attributes 4.0 licence.

\section{ABSTRACT}

We analyzed 11 samples of wastewater, sludge and soil contaminated with acrylic acid nitrile, acrylamide and acrylic acid from the territory of Navoiyazot JSC (Navoi, Uzbekistan). As a result, 19 strains belonging to the bacteria of the genus Rhodococcus were isolated into a pure culture. In the process of selection, 2 strains of bacteria were selected that exhibit the highest amidase activity for acrylic acid (0.712 U/mg and $0.868 \mathrm{U} / \mathrm{mg}$ ). Strains of Rhodococcus sp. - 8/4/1 and Rhodococcus sp. $3 / 4 / 3$ are potential amidase producers.

\section{KEYWORDS}

Strain, Acrylic Acid, Producer, Amidase, Enzyme Activity.

\section{INTRODUCTION}

Rhodococci possess a high level of adaptation to extreme conditions of existence $[1,2]$, are characterized by such unique biological properties as pleomorphism, the ability to coaggregate, have a complex morphogenetic development cycle, and these characteristics determine the presence of various methods of cell cooperation [3]. Cooperation promotes the establishment of cell contact with each other, their retention in colonies, adsorption 
on the surface of drops of hydrophobic substrates and soil particles, as well as the formation of biofilms on the surface of carriers used in biotechnological processes.

Rhodococci have been isolated from various sources, such as soil, groundwater, marine sediments, internal organs of insects, sick and healthy animals or plants $[1,2,5]$. They are widely used in the bioconversion of various organic substrates [6]. The multi-ton synthesis of acrylamide (AA) over many years, launched at several production sites around the world, is regarded as the most outstanding example of the cellular process for this group of bacteria, as well as the possibility of being used as biocatalysts for the production of other useful chemicals, in particular, acrylic acid. Acrylic acid is a raw material for the production of polymers and copolymers for various purposes, widely used in all spheres of the national economy [7-10].

In this regard, the aim of this work is to isolate local strains of bacteria - producers of nitrile transforming enzymes, in particular amidases, and to assess the possibility of their use for obtaining acrylic acid.

\section{MATERIALS AND RESEARCH METHODS}

To isolate microorganisms with amidase activity, wastewater, sludge and soil contaminated with nitrile acrylic acid, acrylamide and acrylic acid JSC "Navoiyazot" (Navoi, Uzbekistan) were used.

The strains were isolated by the method of enrichment culture and direct seeding. In the case of direct seeding, a soil sample of $10 \mathrm{~g}$ was suspended in $100 \mathrm{ml}$ of sterile phosphate buffer, defended at a temperature of $25-27^{\circ} \mathrm{C}$ for 1 hour, the supernatant liquid in an amount of $100 \mu \mathrm{l}$ was applied to the surface of the agar medium Nutrient agar (Himedia, India) containing acetonitrile at a concentration of 2 $-5 \%$, acrylonitrile at a concentration of $0.1-1 \%$ and rubbed with a spatula. In the case of using sludge or effluents as samples, the samples were not diluted in phosphate buffer, inoculation was made directly into nutrient agar.

To grow enrichment cultures and isolate nitrileconverting strains of microorganisms, $10 \mathrm{~g}$ or $10 \mathrm{ml}$ of the sample was added to nutrient media: Tryptone-soy broth (Himedia, India) or peptone-containing (PS) medium ( $\mathrm{g} / \mathrm{L}$ ): peptone - 5.0, $\mathrm{KH}_{2} \mathrm{PO}_{4}-0.5, \mathrm{MgSO}_{4} * 7 \mathrm{H}_{2} \mathrm{O}-$ $0.5, \mathrm{NaCl}-0.5, \mathrm{CoCl}_{2} * 6 \mathrm{H}_{2} \mathrm{O}-0.01$ and glucose - 10.0 with the addition of acetonitrile and acrylonitrile, the $\mathrm{pH}$ of the medium is 7.0-7.3.

Identification of strains was carried out on the basis of cultural, morphological and biochemical characteristics according to Bergey's guide, guidelines of I.B. Ivshina and O.A. Nesterenko $[1,2,11]$.

The morphology and life cycle of the strains were studied during $6,12,18,48,72$ hours of cultivation on nutrient agar (HIMEDIA) and liquid nutrient medium PS using light microscopy.

The transformation of NAA into AA and Acrylic acid was carried out using the biomass of the studied strains, preliminarily grown in a liquid nutrient medium PS, in $10 \mathrm{mM}$ potassium phosphate buffer, $\mathrm{pH} 7.5$, with a concentration of NAA of $1-2 \%$. The reaction was carried out at a temperature of $20-25^{\circ} \mathrm{C}$ for 10 and $30 \mathrm{~min}$ and was stopped by the addition of $0.1 \mathrm{ml}$ of $1 \mathrm{~N}$ 
hydrochloric acid. $\mathrm{HCl}$. The samples were centrifuged at $12000 \mathrm{rpm}$ for $7 \mathrm{~min}$. The concentration of AA and Acrylic acid was determined in the supernatant using high performance liquid chromatography (HPLC). Serial dilutions of pure preparations of NAC, $A A$, and Acrylic acid were used as a control.

\section{RESULTS AND DISCUSSION}

To isolate active strains of microorganisms capable of transforming nitriles, samples of wastewater, silt and soil contaminated with NAC, AA and Acrylic acid were analyzed. Sampling was carried out from the territory of production of JSC "Navoiyazot" in the areas where the production facilities for the production of NAC and Acrylic acid are located. In order to isolate active strains capable of transforming NAA into AA and Acrylic acid, 11 samples were analyzed. Individual colonies of microorganisms were isolated by the method of enrichment culture and direct seeding. As a result, 19 strains were isolated from wastewater, silt and soil samples into a pure culture.

All investigated strains are gram-positive aerobes, immobile, non-acid-resistant, nonspore-forming. Cells are rod-shaped, weakly branching. V-shaped arrangement of cells is characteristic. A distinctive feature of the studied strains is a three-stage morphogenetic development cycle (cocci - rod-shaped, filamentous or branching cells - cocci). On nutrient agar at a temperature of $28^{\circ} \mathrm{C}, \mathrm{pH}=$ 7.0, colonies of a soft consistency without aerial mycelium with pink, dark pink, orange- red non-defunding pigments are formed. On the basis of morphological and cultural properties, the isolated strains were assigned to the genus Rhodococcus.

Isolated in pure culture strains of bacteria belonging to the genus Rhodococcus were studied for their ability to synthesize amidase. The ability of isolated strains of bacteria of the genus Rhodococcus to transform NAA into AA and Acrylic acid was studied using cell biomass. The cultures were grown in a liquid nutrient medium PS for 72 - 96 hours, then the cells were precipitated by centrifugation, the sediment was used for the ability of cultures to transform NAC into AA and Acrylic acid.

As a result of the screening, 2 strains with amidase activity for acrylic acid were selected. It was found that strains of Rhodococcus sp. 8/4/1 and Rhodococcus sp. - 3/4/3 synthesize amidase with activity $0.712 \mathrm{U} / \mathrm{mg}$ and $0.868 \mathrm{U}$ $/ \mathrm{mg}$, respectively. It is known that some strains of rhodococci, such as $\mathrm{R}$. rhodochrous M-33 and $\mathrm{R}$. ruber $\mathrm{GT} 1$, have high nitrile hydrolysis activity, which determined their use in the industrial synthesis of acrylamide [13, 14].

During the biotransformation of NAC, acrylamide and acrylic acid were detected in the medium. This made it possible to establish the presence of a nitrile hydratase-amidase metabolic pathway in the strain, i.e. enzyme system nitrile hydratase / amidase of the Rhodococcus sp. - 8/4/1 converts NAC to AA in two stages: nitrile hydratase converts NAC to $A A$, which is then converted to Acrylic acid by the action of amidase. 
The American Journal of Interdisciplinary Innovations and Research (ISSN-2642-7478)

Published: December 30, 2021 | Pages: 5-9

Doi: https://doi.org/10.37547/tajiir/Volume03Issue12-02

Screening of isolated strains of bacteria of the genus Rhodococcus with amidase activity

\begin{tabular}{|c|c|c|}
\hline № & Bacterial culture strains & Amidase activity ( $\mathrm{U} / \mathrm{mg}$ ) \\
\hline 1 & Rhodococcus sp. - 8/4/1 & 0,712 \\
\hline 2 & Rhodococcus sp. - 8/2/1 & - \\
\hline 3 & Rhodococcus sp. $-8 / 2 / 2$ & - \\
\hline 4 & Rhodococcus sp. $-1 / 1$ & 0,050 \\
\hline 5 & Rhodococcus sp.- $п 1 / 5 / 1$ & 0,037 \\
\hline 6 & Rhodococcus sp.- 3/5/1 & - \\
\hline 7 & Rhodococcus sp.- $3 / 1$ CAAK & 0.324 \\
\hline 8 & Rhodococcus sp.- $3 / 4 / 3$ & 0,868 \\
\hline 9 & Rhodococcus sp - 2/5 & 0,460 \\
\hline 10 & Rhodococcus sp.- $2 / 3 / 6$ & 0,226 \\
\hline 11 & Rhodococcus sp. - 5/3 & - \\
\hline 12 & Rhodococcus sp.- 52 & - \\
\hline 13 & Rhodococcus sp. - 3/5/2 & - \\
\hline 14 & Rhodococcus sp.3/2/2 & 0,115 \\
\hline 15 & Rhodococcus sp. 2/3/6 cp & 0,114 \\
\hline 16 & Rhodococcus sp. 3/2/1Sf & 0,115 \\
\hline 17 & Rhodococcus sp. 2/4/2 & 0,112 \\
\hline 18 & Rhodococcus sp. $п 2 / 7 / 2$ & 0,230 \\
\hline 19 & Rhodococcus sp. 3/7 (32) & - \\
\hline
\end{tabular}

\section{CONCLUSION}

The strains of Rhodococcus sp. - 8/4/1 and Rhodococcus sp. - 3/4/3 are potential amidase producers. Further improvement of this strain will serve to obtain a potential biocatalyst for the biocatalytic synthesis of acrylic acid.

\section{REFERENCES}

1. Ivshina, I.B. The genus Rhodococcus bacteria: biodiversity, detection, immunoassay. Doctoral thesis. Perm, 1997. (In Russ.).

2. Ivshina, I.B., Kamenskikh, T.N., Anokhin, B.A. Adaptive mechanisms of 
alkanotrophic rhodococci survival under unfavorable conditions. Bulletin of Perm University, V. 5 (10) (2007). P. 107-112. (In Russ.).

3. Kim D., Choi K.Y., Yoo M., Zylstra G.J., Kim E. Biotechnological potential for biodegradation of Rhodococcus. J. Microbiol. Biotechnol.2018 V.28 (7). P. 1037-1051

4. Alvarez, H.M. Biology of Rhodococcus, 2nd ed.; Springer: Basel, Switzerland, 2019.

5. Larkin, M.J.; Kulakov, L.A.; Allen, C.C.R. Biodegradation by Members of the Genus Rhodococcus: Biochemistry, Physiology, and Genetic Adaptation. Adv. Appl. Microbiol. 2006, 59, 1-29. [PubMed]

6. Zampolli, J.; Zeaiter, Z.; Di Canito, A.; Di Gennaro, P. Genome analysis and omics approaches provide new insights into the biodegradation potential of Rhodococcus. Appl. Microbiol. Biotechnol. 2019, 103, 1069-1080. [CrossRef] [PubMed]

7. Abdelraheem, E.M.M.; Busch, H.; Hanefeld, U.; Tonin, F. Biocatalysis explained: From Pharmaceutical to Bulk Chemical Production. React. Chem. Eng. 2019. [CrossRef]

8. Gröger, H.; Asano, Y.; Bornscheuer, U.T.; Ogawa, J. Development of biocatalytic processes in Japan and Germany: From research synergies to industrial applications. Chem. Asian J. 2012, 7, 1138-1153. [CrossRef][PubMed]

9. Ogawa, J.; Shimizu, S. Industrial microbial enzymes: Their discovery by screening and use in large-scale production of useful chemicals in
Japan. Curr. Opin. Biotechnol. 2002, 13, 367-375. [CrossRef]

10. Neerja Thakur, Vijay Kumar, Nirmal Kant Sharma, Shikha Thakur, Tek Chand Bhalla. Aliphatic Amidase of RhodococcusRhodochrous PA-34: Purification, Characterization and Application in Synthesis of Acrylic Acid Protein Pept Lett 2016;23(2):152-8.

11. Nesterenko O.A., E.I. Krasnikov, T.M. Nogina. Nocardi-like nocardioform bacteria - Kiev: Naukova Dumka - 1985 P. 336.

12. O.A. Gimadutdinov, A.R. Kayumov Workshop on Molecular Genetics. Study guide. Kazan, KFU (2016), p. 36. 